\title{
Determining the Compliance of Intern Nursing Students with Isolation Precautions in the COVID-19 Pandemic Period
}

\section{COVID-19 Pandemisi Döneminde İntörn Hemşirelik Öğrencilerinin İzolasyon Önlemlerine Uyumunun Belirlenmesi}

(i) Duygu KURT ${ }^{1}$, iD Seda SÜMER DALKIRAN2

1Trakya University Keşan Hakkı Yörük Faculty of Health, Department of Nursing, Edirne, Turkey

2University of Health Sciences Turkey Hamidiye Faculty of Health Sciences, Department of Midwifery, İstanbul, Turkey

\section{ABSTRACT}

Objective: This study aimed to determine the compliance of intern nurses with isolation precautions in the coronavirus disease-19 (COVID-19) pandemic period.

Methods: This descriptive and cross-sectional study was conducted with 4th-year intern nurses $(n=90)$ receiving education at the vocational school of health of a state university in November 2020. The data were collected by using a Questionnaire Form and the "Isolation Precautions Compliance Scale". In data analysis, percentage, mean, Kruskal-Wallis test and Mann-Whitney U test were used in the SPSS software.

Results: The mean age of the intern nurses who participated in the study was $22 \pm 1.43$ years, $74.4 \%$ were female, $51.1 \%$ were graduates of Anatolian high schools. Intern nurses $95.6 \%$ had received training on isolation precautions, and $81.1 \%$ received this training from a course instructor during their undergraduate studies. In was determined that $71.1 \%$ of the participants provided nursing care for patients who were under isolation during clinical practice, and $91.1 \%$ had knowledge that isolation precautions need to be implemented in the nursing care of patients diagnosed with COVID-19. The mean Isolation Precautions Compliance Scale total score of the participants was $71.92 \pm 5.74$. There was no significant difference in the mean Isolation Precautions Compliance Scale total scores of the participants based on their sociodemographic characteristics and isolation precautions.

Conclusion: It was determined that the compliance of the intern nursing students, whose nursing labor could be needed in the

\section{ÖZ}

Amaç: Araştırma, koronavirüs hastalığı-19 (COVID-19) pandemisi döneminde intörn hemşirelerin izolasyon önlemlerine uyumlarının belirlenmesi amacıyla yapılmıştır.

Yöntemler: Tanımlayıcı ve kesitsel tipteki bu araştırma, Kasım 2020 tarihinde bir devlet üniversitesinin sağlı yüksekokulunda öğrenim gören 4. sınıf intörn hemşireler $(n=90)$ ile gerçekleştirildi. Veriler, Kişisel Bilgi Formu ve "İzolasyon Önlemlerine Uyum Ölçeği” kullanılarak toplandı. Verilerin değerlendirilmesinde yüzde, ortalama, Kruskal-Wallis testi ve Mann-Whitney U testi kullanıldı.

Bulgular: Araştırmaya katılan intörn hemşirelerin yaş ortalaması $22 \pm 1,43$ yıl olup, \%74,4’ü kadın, \%51,1'i anadolu lisesi mezunudur. Öğrencilerin \%95,6'sının izolasyon önlemleri hakkında eğitim aldığ ve $\% 81,1$ 'inin bu eğitimi lisans öğreniminde öğretim elemanı/üyesinden aldığı bulundu. Katılımcıların \%71,1'inin klinik uygulama esnasında izolasyon uygulanan hastaya hemşirelik bakımı verdiği ve \%91,1'inin COVID-19 tanılı hastanın hemşirelik bakımında izolasyon önlemlerinin uygulanması ile ilgili bilgi sahibi olduğu belirlendi. Öğrencilerin izolasyon önlemlerine uyum ölçeği toplam puan ortalaması 71,92 $\pm 5,74$ olarak bulundu. Öğrencilerin sosyodemografik özellikleri ve izolasyon uygulamaları ile izolasyon önlemlerine uyum ölçeği toplam puan ortalamaları arasında istatistiksel olarak anlamlı farklılık olmadığı saptandı.

Sonuç: COVID-19 pandemisi döneminde hemşirelik iş güçlerine ihtiyaç duyulabilecek intörn hemşirelerin izolasyon önlemlerine uyumlarının iyi düzeyde olduğu belirlendi.
Address for Correspondence: Duygu KURT, Trakya University Keşan Hakkı Yörük Faculty of Health, Department of Nursing, Edirne, Turkey

E-mail: duygukurt@trakya.edu.tr ORCID ID: orcid.org/0000-0003-4899-0907
Received: 10.11 .2020

Accepted: 09.02.2021

Cite this article as: Kurt D, Sümer Dalkıran S. Determining the Compliance of Intern Nursing Students with Isolation Precautions in the COVID-19 Pandemic Period. Bezmialem Science 2022;10(4):493-9 
COVID-19 pandemic period, with isolation precautions was on a good level.

Keywords: COVID-19 pandemic, internship, isolation, nurse
Anahtar Sözcükler: COVID-19 pandemisi, intörn, izolasyon, hemşire

\section{Introduction}

The World Health Organization (WHO) reported patients with pneumonia of unknown etiology in the city of Wuhan, Hubei province of China, on 31 December 2019. These patients were identified as infected by a new coronavirus (2019-nCoV) which was not detected in humans before on January 7, 2020. Later, the name of the 2019-nCoV disease was determined as coronavirus disease-19 (COVID-19) (1). WHO classified COVID-19 as an international public health emergency on 30 January 2020. The disease was declared as a pandemic by WHO on March 11, 2020, due to the spread of the virus and severity of the disease, and its occurrence in 113 countries outside of China, where COVID-19 first started $(1,2)$. The first case of COVID-19 in our country was detected on March 11, 2020 (1). WHO reported that as of January 24, 2021, COVID-19 had spread to 224 countries and caused 2,098,879 deaths (2).

Despite all the precautions taken in the world and in our country, the COVID-19 pandemic continues and the number of morbidity and mortality is increasing (2-4). Not knowing when the pandemic will end puts responsibilities on universities as well as health services (3). There are countries that give an active role in the field to nursing students in the last years of their undergraduate education in the fight against the pandemic $(5,6)$. This has not been the case in our country, and most universities have postponed the clinical and internship practices of nursing departments due to the COVID-19 pandemic.

Internship system is implemented in many universities in our country (7). In this system, senior nursing students, who have gained a certain professional knowledge and skill, are given an active role as an intern nurse in the field and gain professional awareness and experience before graduation (8). The insufficiency of nurses struggling with the pandemic due to overwork, increased workload or the emergence of the need for nurses as a result of being infected is a situation that may cause intern nurses to be needed in the field. In addition, if the pandemic continues, intern nurses will have to complete their clinical practice in this environment and will take an active role in the pandemic when they graduate $(3,6,9)$.

Adequate and correct application of infection control measures by nurses in the clinical management of COVID-19 is important in breaking the chain of infection (10-12). Nurses are at risk of transmission of COVID-19 during the care and treatment of patients, and they have responsibilities both for themselves and for the prevention of transmission in the healthcare setting $(7,9,12)$. The causative agent of COVID-19 is transmitted from person to person through droplets, contact and, in some cases, aerosols. Therefore, isolation measures should be applied to patients with COVID-19 $(11,13)$. Isolation is the separation of the patient in order to prevent the transmission of microorganisms from the infected patient to health professionals, other patients and visitors. Isolation precautions are divided into two as standard and contagious precautions (14). Isolation measures to be applied to patients diagnosed or suspected as having COVID-19 include contact and droplet isolation for transmission in addition to standard precautions (15).

The knowledge and attitudes of intern nurses who can work in the field during the COVID-19 pandemic period regarding isolation measures are extremely important in terms of safe, quality and sustainable health care (16-19). In this study, it is aimed to determine the compliance of intern nurses with isolation measures during the COVID-19 pandemic period.

\section{Methods}

\section{Purpose and Type of Research}

This research was carried out in a descriptive and cross-sectional type with the aim of determining the compliance of intern nurses with isolation measures during the COVID-19 pandemic period.

\section{Population and Sample of the Research}

The universe of the research consisted of $4^{\text {th }}$ grade intern nurses studying at a public university health school in November 2020 $(n=90)$. Sample calculation was not made in the study, and the entire universe was reached.

\section{Data Collection Tools}

Personal Information Form and Isolation Precautions Compliance Scale were used to collect data.

Personal Information Form: The personal information form developed by the researchers in line with the literature consists of 7 questions to determine the sociodemographic characteristics of intern nurses (age, gender, graduated high school) and isolation practices (training about isolation, caring for isolated patients, etc.) $(10,20-25)$.

Isolation Precautions Compliance Scale: The scale, which was developed by Tayran and Ulupinar (16) in 2011 and of which validity and reliability studies were conducted, consisted of 18 items and 4 sub-dimensions. These sub-dimensions are; route of transmission (items 3, 8, 9, 10 and 11), employee and patient safety (items 2, 5, 12, 14, 16 and 17), environmental control (items 1, 13, 15 and 18), and hand washing and the use of gloves (items 4, 6 and 7). It is a five-point Likert type ( $1=$ strongly disagree, $2=$ disagree, $3=$ no idea, $4=$ agree, and $5=$ strongly agree). Items 5, 7, 12 and 17 in the scale are negative statements. The total scores that can be obtained from the scale vary between 18-90 points, and an increase in the score indicates that nurses' compliance with isolation measures increases. The authors of the 
scale suggest the use of the scale as one-dimensional. In the study of Tayran and Ulupınar (16), the Cronbach alpha value of the scale was found to be 0.85 . In this study, it was found to be 0.79 .

\section{Data Collection}

Intern nurses were reached online after obtaining the necessary permissions to conduct the research. Students were asked to answer the Personal Information Form and Isolation Precautions Compliance Scale by explaining to the students the purpose of the research, the identity information and the information they provided would be kept confidential by complying with the ethical principle of confidentiality and secrecy.

\section{Ethical Aspect of Research}

In order to carry out the research, ethics committee approval was obtained from the Scientific Research Ethics Committee of the Trakya University Faculty of Medicine with the date 12.10.2020 and number 2020/326, and the institutional permission was obtained from the Y School Directorate with the date 09.11.2020 and number 33505391-044-E.472785. In accordance with the Declaration of Helsinki, the purpose of the study was explained to the intern nurses who constituted the sample of the study. It was informed that the participation was voluntary and that the personal information and privacy of the participants would be protected.

\section{Evaluation of Data}

The data obtained in the research were analysed by using the SPSS 21.0 package program. The compatibility of the variables with normal distribution was evaluated with the Kolmogrov-Smirnov test and it was found that the data did not show compliance with the normal distribution. While evaluating the study data, nonparametric tests such as Kruskal-Wallis test and Mann-Whitney $\mathrm{U}$ test were used for comparisons between groups as well as descriptive statistical methods (number, percentage, mean, standard deviation). Statistical significance level was accepted as $\mathrm{p}<0.05$.

\section{Results}

The average age of the intern nurses participating in the study was $22 \pm 1.43$ years. It was determined that $74.4 \%$ of the students were women, 51.1\% were Anatolian high school graduates, 95.6\% received training on isolation precautions and $81.1 \%$ received this training from an instructor/member in their undergraduate education. It was found that $71.1 \%$ of the participants provided nursing care to the patients who were isolated during clinical practice, and $91.1 \%$ had knowledge about the need to apply isolation measures in the nursing care of a patient with a diagnosis of COVID-19 (Table 1).

In our study, the average score of the intern nurses on the Isolation Precautions Compliance Scale was 71.92 \pm 5.74 , and the subdimension mean scores of the scale was as follows; $23.66 \pm 2.25$ for route of transmission, $18.81 \pm 2.56$ for employee and patient safety, $18.42 \pm 1.86$ for environmental control, $11.02 \pm 1.28$ for hand hygiene and use of gloves (Table 2).
Intern nurses participating in the study had knowledge about gender, graduated high school, getting training about isolation precautions, where and from whom they received training on isolation measures, providing nursing care to the patients who were isolated during clinical practice, and the need for isolation measures to be applied in the nursing care of the patient with COVID-19. It was determined that there was no statistically significant difference between the characteristics of being an individual and the mean scores of the Isolation Precautions Compliance Scale ( $\mathrm{p}>0.05)$ (Table 3).

\section{Discussion}

In this study, which aimed to determine the compliance of intern nurses with isolation precautions, the total score average of the students' Isolation Precautions Compliance Scale was 71.92 \pm 5.74 . Accordingly, it could be said that the students' compliance with the isolation measures was at a good level. It is expected that nursing students who are studying at the undergraduate level and who are entitled to be interns by completing the theoretical courses in this education have a good level of compliance with isolation measures. Because nursing education at the undergraduate level plays an important role in helping students acquire the right knowledge, attitude and skills (10). Most of the students who participated in our study stated that they received the training about compliance with isolation measures during their undergraduate education.

In the literature, there are no other studies evaluating the compliance of nursing students with isolation precautions, both in the world and in our country, but there are studies evaluating nurses $(10,20,21)$. In these studies with nurses, the level of compliance of nurses with isolation measures is higher than the intern nurses participating in our study. It is thought that this situation is due to the fact that the clinical experience of the students is less than that of the nurses. In the literature, it is stated that experience increases nurses' compliance with isolation measures (20,22-25). The fact that the students who participated in our study did not have clinical experience other than clinical practices and that only $71.1 \%$ of them gave care to the patients in isolation in these clinical practices supported the literature.

During the pandemic process, nursing department students should have knowledge about COVID-19 (9). The majority of the students $(91.1 \%)$ who participated in our study had knowledge about the necessity of following isolation precautions in the nursing care of patients with COVID-19. However, in our study, intern nurses who were not informed about the need to comply with isolation precautions in the nursing care of patients with COVID-19 were more likely to comply with isolation measures $(p>0.005)$. It is thought that this situation is due to the fact that intern nurses are generally well-adapted to isolation measures, even if they do not have the experience of caring for a patient with a diagnosis of COVID-19, and cannot go to clinical practice during the COVID-19 pandemic. Implementation of isolation measures in the nursing care of patients with a diagnosis of COVID-19 is critical to prevent transmission $(11,26)$. Studies have shown that the knowledge and awareness of nursing 
Table 1. Sociodemographic features and isolation practices of intern nurses $(n=90)$

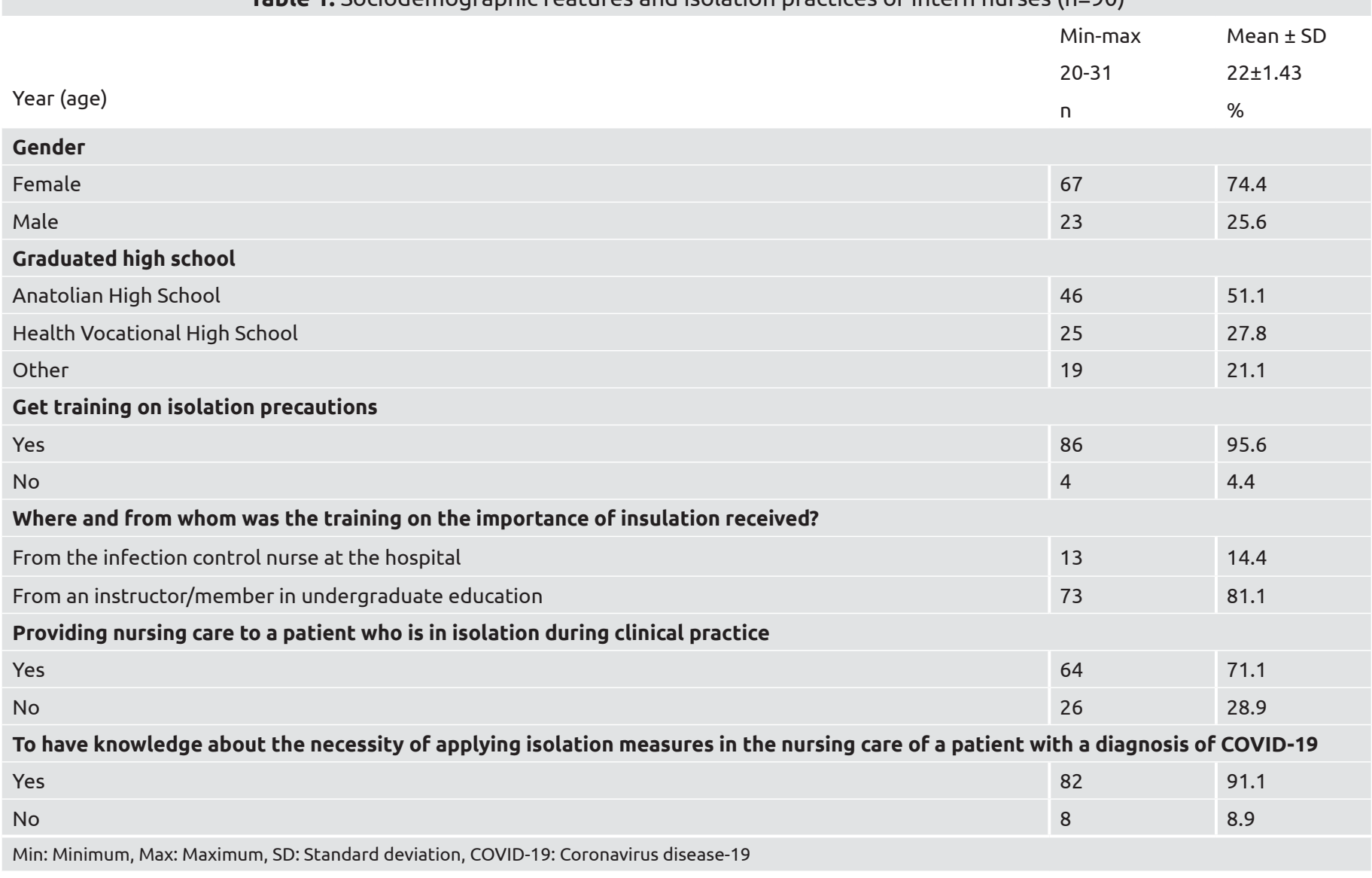

Table 2. The mean scores of the total and sub-dimensions of the Intern Nurses' Isolation Precautions Compliance Scale

Scale and its sub-dimensions
Compliance with Isolation Measures Scale total score
Transmission route
Employee and patient safety
Environmental control
Hand hygiene, use of gloves

SD: Standard deviation, Min: Minimum, Max: Maximum

department students about COVID-19 is good or moderate $(9,27,28)$ and that the majority of students $(75 \%)$ know the infection control measures to be followed in COVID-19 (9). In a study conducted with intern nurses, it was concluded that it was important for students to have knowledge about infection control measures before starting the profession (29). In a study conducted with nursing students in Korea, it was determined that infection was prevented as students' knowledge and attitudes towards infection control increased (30).

In the study, the level of compliance with the isolation precautions of the intern nurses who received training from the infection control nurse in the hospital about the importance of isolation was higher $(p>0.005)$. Isolation measures are an issue in the nursing education curriculum. It was thought that the information that the students received from the infection control nurse in clinical practices after the training they received about isolation measures at school increased their level of compliance with isolation measures.

In our study, it was determined that the compliance of the intern nurses who did not care for the patient who was isolated in clinical practice was higher $(\mathrm{p}>0.05)$. In a study where nurses' compliance with isolation measures was determined, it was determined that nurses who did not apply isolation, similar to our finding, had higher compliance with isolation measures ( $p>0.05$ ) (25). This finding might indicate that the intern nurses, who did not have experience in caring for the isolated patient, learned the isolation practices well in the education they received at school. Supporting intern nurses' knowledge about isolation precautions with clinical practice rather than being limited to theoretical education can significantly increase their compliance with isolation precautions. 
Table 3. Comparison of the sociodemographic characteristics and isolation practices of the intern nurses and the total score averages of the Isolation Precautions Compliance Scale

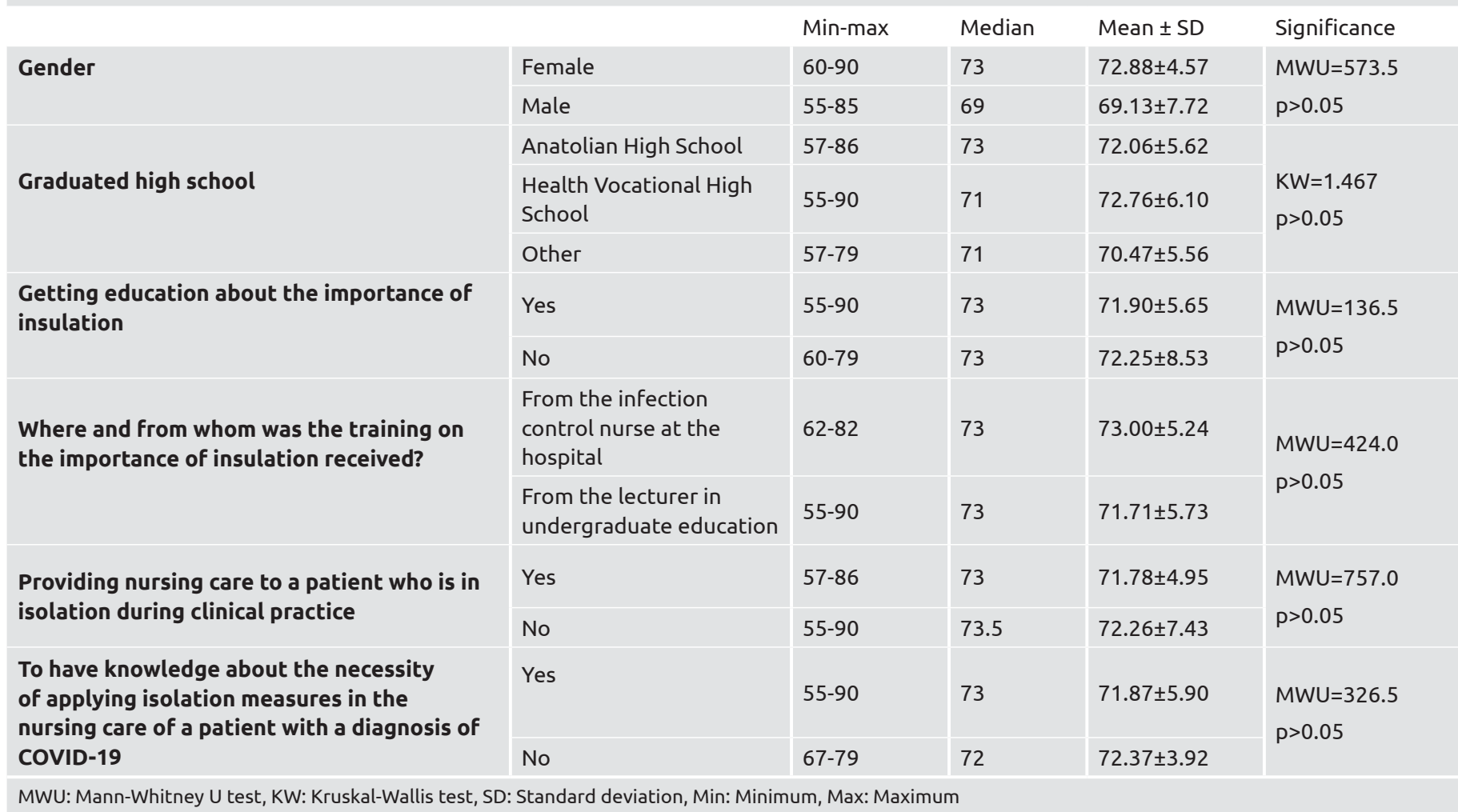

Nurses are health professionals who are at the forefront and play a key role in the fight against the COVID-19 pandemic (24). In order for the pandemic to be managed perfectly, nurses must be sufficiently ready in terms of quantity and quality. Due to the increased workload of nurses and the risk of contamination during the pandemic, increasing the number of nurses in case the number of nurses is affected is an important initiative to prevent the pandemic $(6,9,26)$. Ensuring adequate nurse workforce management in case of need may be possible by assigning responsibilities to intern nurses $(6,31,32)$. In a study conducted with nursing students involved in the fight against COVID-19, it was reported that students were afraid of COVID-19 and the workload of the clinics, but they were aware of their responsibilities towards the society (33). Within the scope of both global and national struggle against COVID-19, intern nurses who are health professional candidates should be ready, aware and knowledgeable about the pandemic (34). Effective fight against the pandemic will be facilitated by scientific measures to be taken by health professionals with enhanced awareness (18).

\section{Study Limitations}

The limitation of the study was that it only covered intern nurses studying at a university.

\section{Conclusion}

In this study, it was determined that the level of compliance of intern nurses to isolation measures was good during the COVID-19 pandemic period. Most of the students knew that isolation precautions should be followed in the nursing care of patients diagnosed as having COVID-19. The results showed that intern nurses, whose nursing workforces might be needed during the pandemic period, had knowledge and awareness about isolation measures. It is recommended to keep the knowledge and awareness of nursing students at a high level by including the current developments that may arise during the pandemic process into the nursing education curriculum.

\section{Ethics}

Ethics Committee Approval: In order to carry out the research, ethics committee approval was obtained from the Scientific Research Ethics Committee of the Trakya University Faculty of Medicine with the date 12.10.2020 and number 2020/326, and the institutional permission was obtained from the Trakya University Keşan Hakkı Yörük School of Health Directorate with the date 09.11.2020 and number 33505391-044-E.472785.

Informed Consent: In accordance with the Declaration of Helsinki, the purpose of the study was explained to the intern nurses who constituted the sample of the study.

Peer-review: Externally peer reviewed.

\section{Authorship Contributions}

Concept: D.K., S.S.D., Design: D.K., S.S.D., Data Collection or Processing: D.K., S.S.D., Analysis or Interpretation: D.K., S.S.D., Literature Search: D.K., S.S.D., Writing: D.K., S.S.D.,

Conflict of Interest: No conflict of interest was declared by the authors. 
Financial Disclosure: The authors declared that this study received no financial support.

\section{References}

1. T.C. Sağlık Bakanlığı Halk Sağlığı Genel Müdürlüğü. COVID-19 (SaRS-CoV2 Enfeksiyonu) Genel Bilgiler, Epidemiyoloji ve Tan1, 2020. https://covid19bilgi.saglik.gov.tr/depo/rehberler/ covid-19-rehberi/COVID 19_REHBERI_GENEL_BILGILER_ EPIDEMIYOLOJI_VE_TANI.pdf (Erişim Tarihi: 11.11.2020)

2. Who Health Organization. Coronavirus disease (COVID-19) pandemic, 2020. https:/www.who.int/emergencies/diseases/novelcoronavirus-2019 (Erişim Tarihi: 24.01.2021)

3. Dewart G, Corcoran L, Thirsk L, Petrovic K. Nursing education in a pandemic: Academic challenges in response to COVID-19. Nurse Educ Today 2020;92:104471.

4. Dikmen A, Kına HM, Özkan S, İlhan MN. Epidemiology of COVID-19: What We Learn From Pandemic. J Biotechnol and Strategic Health Res 2020; 1(Özel Sayı):29-36.

5. Franzoi MAH, Cauduro FLF. Participation of nursing students in the COVID-19 Pandemic. Cogitare Enfermagem 2020;25:e73491.

6. Cengiz Z. Salgının sağlık personeli üzerindeki etkileri. İçinde: Aylaz R, Yılmaz E, editörler. Yeni Koronavirüs Hastalığının Toplum Üzerine Etkileri Ve Hemşirelik Yaklaşımları. Malatya:İnönü Üniversitesi Yayın Evi; 2020.s.206-15.

7. Ateş N, Güçlüel Y, Pirecioğlu Y, Güngörmüş E, Yıldırım A. Opinions and Recommendations of Intern Nurse, Mentor Nurse and Clinical Responsible Nurse about Intern Clinical Practice Program. Hemşirelikte Araştırma Geliştirme Dergisi 2017;19:1-11.

8. Gökalp K, Durmaz H, Orak OS. Intern Nurses In Nurses Opinions. GÜSBD 2018;7:80-5.

9. Joshi KP, Madhura L, Jamadar D. Knowledge and awareness among nursing students regarding the COVID-19: a cross sectional study. Int J Community Med Public Health 2020;7:2518-21.

10. Şatır DG, Güneri SE, Öztürk R, Maraş GB, Mertoğlu A, Sevil Ü. Evaluating the Compliance and Factors Affecting With Isolation Precautions of Nurses: Izmir Sample. Tepecik Eğit ve Araşt Hast Dergisi 2019;29:218-22.

11. Annak İM, Karaveli EÖ. Isolation Measures That Nurses Should Take in The Care of COVID-19 Diagnosed Patients. YIU Saglik Bil Derg 2020;1:48-52.

12. Demirağ H, Hintistan S. Clinical Management and Nursing of COVID-19. GÜSBD 2020;9:222-31.

13. T.C. Sağlık Bakanlığı Halk Sağlığı Genel Müdürlüğü. COVID-19 (SaRS-CoV2 Enfeksiyonu) Enfeksiyon Kontrolü ve İzolasyon, 2020. https:/covid19bilgi.saglik.gov.tr/depo/rehberler/covid-19-rehberi/ COVID-19_REHBERI_ENFEKSIYON_KONTROLU_VE_ IZOLASYON.pdf (Erişim Tarihi: 11.11.2020)

14. Sarvan SZ. Enfeksiyon kontrolü ve uygulamaları. İçinde:Ay AF. (editor). Sağlık Uygulamalarında Temel Kavramlar ve Beceriler. İstanbul, Nobel Tip Kitabevleri; 2011.s. 196-243.

15. World Health Organization. Q\&A on corona viruses (COVID-19), 2020. https://www.who.int/emergencies/diseases/novel- coronavirus-2019/question-and-answers-hub/q-a-detail/q-acoronaviruses (Erişim Tarihi: 11.11.2020)

16. Tayran N, Ulupinar S. Development of a Scale Study: Validity and Reliability of a Scale Compliance with Isolation Precautions. İ.Ü.F.N. Hem Derg 2011;19:89-98.

17. Bal EY, Çelik H. COVID-19 salgını ile mücadelede hemşirenin rolü. Turkiye Klinikleri J Nurs Sci 2020;12:300-4.

18. Yılmaz A, Dinçer NÜ, Kazan EE. COVID-19 Pandemic and Isolation Precautions for Health Workers. Turkiye Klinikleri J Health Sci 2020;5:384-93.

19. World Health Organization (WHO). Report of the WHO-China Joint Mission on Coronavirus Disease 2019 (COVID-19) clinical management of severe acute respiratory infection when novel Coronavirus infection is suspected, 2020. https://www.who.int/docs/ default-source/coronaviruse/who-china-joint-mission-on-covid-19final-report.pdf (Erişim Tarihi: 11.11.2020)

20. Zencir G, Bayraktar D, Khorshid L. Nurses' compliance with isolation precautions worked in a publıc hospttl. Ege Üniversitesi Hemşirelik Fakültesi Dergisi 2013;29:61-70.

21. Erden S, Kahraman BB, Bulut H. Evaluation of compliance of physicians and nurses with isolation precautions in intensive care units. Gümüşhane University Journal of Health Sciences 2015;4:38898.

22. Özden D, Özveren H. Determining the Professional and Organizational Factors in Nurses' Compliance with Isolation Precautions. JAREN 2016;2:24-32.

23. Arli SK, Bakan AB. Nurses' compliance with isolation precautions and the affecting factors. Appl Nurs Res 2017;38:175-8.

24. Abdulraheem IS, Amodu MO, Saka MJ, Bolarinwa OA, Uthman MMB. Knowledge, awareness and compliance with standard precautions among health workers in north eastearn Nigeria. J Community Med Health Edu 2012;2:1-5.

25. Yenigün MY. Hastanede çalışan hemşirelerin izolasyon önlemlerine uyumu. Konya, Selçuk Üniversitesi. 2019.

26. Choi KR, Jeffers KS, Logsdon MC. Nursing and the novel coronavirus: Risks and responsibilities in a global outbreak. J Adv Nurs 2020;76:1486-7.

27. Farzana B. Knowledge, attitudes, and practices towards COVID-19 among B.Sc. nursing students in selected nursing institution in Saudi Arabia during COVID-19 outbreak: An Online Survey. Saudi J Nurs Health Care 2020;3:194-8.

28. Varinder K, Jyoti S, Jasbir K, Paramjot K, Simarpreet K. Knowledge and awareness among nursing students towards COVID-19 pandemic: a web-based survey in Northern India. IJSR 2020;9:1-3.

29. Doğu Ö, Karabay O. Infection Control Training Program for Nursing and Midwifery Intern Students. Online Turkish Journal of Health Science 2016;2:1-10.

30. Swift A, Banks L, Baleswaran A, Cooke N, Little C, McGrath L, et al. COVID-19 and student nurses: A view from England. J Clin Nurs 2020;29:3111-4.

31. Chen SC, Lai YH, Tsay SL. Nursing perspectives on the impacts of COVID-19. J Nurs Res 2020;28:e85. 
32. Choi JS, Kim JS. Factors influencing preventive behavior against Middle East Respiratory Syndrome-Coronavirus among nursing students in South Korea. Nurse Educ Today 2016;40:168-72.

33. Lovric R, Farcic N, Miksic S, Vcev A. Studying during the COVID-19 pandemic: a qualitative inductive content analysis of nursing students' perceptions and experiences. Educ Sci 2020;10:1-18.
34. Santos LMD. The relationship between the COVID-19 pandemic and nursing students' sense of belonging: the experiences and nursing education management of pre-service nursing professionals. Int J Environ Res Public Health 2020;17:5848. 